\title{
The Effect of Regular Practice with Cloze Passages on EFL Students' Reading Ability
}

\author{
Davood Borzabadi Farahani \\ Faculty of Foreign Languages and Literatures, University of Tehran, Iran \\ Email: borzabad@ut.ac.ir
}

\begin{abstract}
As completing blanks in a cloze passage requires use to be made of three main knowledge sources involved in reading comprehension, that is, linguistic, textual, and background knowledge, it was hypothesized that regular practice with cloze passages could lead to the enhancement of the reading ability. To test this hypothesis, two groups of adult Iranian students studying general English were selected. The students in the experimental group (30 students) were given regular practice with fixed-ratio deletion cloze passages for 13 sessions (30 minutes per session). The same passages were given to the students in the control group (30 students). However, the passages in the control group were in full but followed by carefully written comprehension questions. The practice sessions for the control group were also 13 and the time taken to work on each passage was 30 minutes per session. At the end of the treatment phase, the comparison made between the two groups' scores on a standardized reading test in the pretest and posttest stage revealed that those in the experimental group had improved more significantly in reading comprehension than those in the control group, a finding that not only underscores the pedagogical value of the cloze procedure but also points to the significance of a process-oriented approach to the teaching of the reading skill.
\end{abstract}

Index Terms—cloze passage, reading ability, linguistic knowledge, textual knowledge, background knowledge

\section{INTRODUCTION}

As stated by Eskey (2005), research on the processes involved in reading comprehension was hardly ever done in 1960s due to the effect of the then dominant behaviorist approach on pedagogy. However, with the emergence of cognitive psychology in the late 1960s the grip that the behaviorist approach had on applied linguistics was loosened, and scholars began to shift their attention from oral skills to reading and writing as well. Goodman (1967), alluding to reading as a "psycholinguistic guessing game", stated that reading is an ongoing process in which readers select from the reading material certain cues to help them to predict what will come next in the text. And as they read on, their guesses are either confirmed or rejected, sometimes compelling them to modify their initial conjectures to formulate new interpretations that are more in line with what is on the printed page.

Following the same line of argument, Clarke and Silberstein (1977) contended that readers choose cues from texts and link them to what they already know to make predictions. The predictions thus made are later tested against what is selected in readers' further samplings of the reading material. Recapping the same process, Alderson and Urquhart (1984) postulated that this psycholinguistic model of reading is an attestation of the readers' attempt to comprehend through guess-making made possible by way of relating textual and linguistic knowledge to background information.

Studies by Steffensen, Joag-dev, and Anderson (1979), Johnson (1981), Johnson (1982), Obah (1983), Aron (1986), and Nelson (1987) all buttress the afore-mentioned view toward reading, a view that points to the fact that successful reading incorporates a simultaneous use of three sources of language: linguistic, textual, and background. Here linguistic knowledge refers to one's knowledge of lexis, syntax, and semantics; textual knowledge involves one's perception of coherence and cohesion as they are technically discussed by Halliday and Hasan (1976); and the last kind of knowledge embraces whatever one knows about the state of affairs in the real world.

Although from 1990s reading research fragmented into various perspectives (Stanovich,1992) to account for social, neurobiological and political dimensions (Kamil, Intrator, and Kim,2000), the psycholinguistic model has not yet lost its appeal. For example, Alderson (2000), Hughes (2003) and Koda (2005) agree with Bernhardt (1991) that successful reading embraces simultaneous use of linguistic, textual and background knowledge. That is, they subscribe to the same position which was the one prevalent in the 1980s.

If one concedes that a psycholinguistic approach to reading comprehension does make sense, the question would then be: "What can be done to help learners to become more competent in reading?" One of the ways suggested but not adequately researched is the employment of the cloze procedure as a teaching technique. The rationale behind this suggestion, as argued by Heaton (1975) and Cohen (1980), is that the same three sources of knowledge already cited (i.e. linguistic, textual and background) are called for whenever one attempts to complete a cloze passage.

The similarity in nature between what one goes through to fill in the blanks on cloze tests and what one engages in while taking reading tests is attested to by high correlations often reported between the two. Such correlations are usually something over .70 (e.g. Ruddell, 1965; Potter, 1968; Anderson, 1976; Hinofotis, 1980). Lee (2008), referring to 
high correlations between cloze and reading tests, states that although the cloze procedure has mostly been regarded as an assessment tool, the similarity between this procedure and reading comprehension in terms of the mental processes that they trigger seems to suggest that it can be utilized as a worthwhile pedagogic tool for the teaching of different aspects of language including the reading ability. Lee $(2008$, p. 644) also corroborates the claim made in this study to the effect that instances of the use of the cloze procedure for teaching purposes are meager.

In fact, those few studies that investigated the use of the cloze procedure for teaching purposes date back to the time when the psycholinguistic model of reading was prevalent, that is, in the 1970s. For example, Stafford (1976) implemented a study to find out how reading comprehension can be promoted in intermediate ESL students. On the assumption that such students are in need of strategies to cope with unfamiliar vocabulary as well as needing practice in syntax, and reading for different purposes, she gave the students in her study regular practice with cloze passages and found such practice to be instrumental in developing the students' capacity to anticipate vocabulary and to demonstrate knowledge of structural relationships. Best (1971) also found that practice with cloze passages improved reading comprehension in young children.

And it is based on the close relationship between the cloze procedure and reading that it is argued by some scholars that this technique can be used for such purposes as diagnosing reading difficulties (Collins-Cheek and Cheek, 1984), teaching reading comprehension (Lunzer and Gardner, 1979; Rye,1980), or measuring reading (Alderson, 2000; Hughes, 2003; Koda, 2005). And it is this same affinity between the cloze procedure and reading that motivated the present researcher to design a study to probe into the potential this integrative measure might have in developing reading comprehension, a topic already addressed more in theory than in practice.

\section{STATEMENT OF THE PROBLEM}

This study was implemented to answer the following question:

Does regular practice with cloze passages cause any significance difference in students' reading ability?

\section{HYPOTHESIS}

To begin with, the research question above was changed to the following null hypothesis:

There occurs no significant difference in their reading ability when students receive regular practice with cloze passages.

\section{METHOD}

\section{A. Participants}

The subjects included 76 male Iranians aged between 15 and 30 studying English at a language institute in Tehran. These students were in Level 5 at the institute where the total number of levels is 14.Hence, such students were lower intermediate students by the institute's standards. There were 36 students in the experimental group and 40 students in the control group. It is to be noted that the students in both the experimental and control groups were divided in two classes each. In other words, there were four classes, two of which served as the experimental and the other two of which as the control group.

It should also be remembered that intact classes were used and that subject mortality was 16 . Hence, at the post-test stage there were 30 students in each group and the 16 students who, for whatever reason did not take the post-test, were excluded from data analysis.

\section{B. Instrumentation}

To assess and compare the subjects' reading ability before and after the treatment, Level A of the Nelson Reading Skills Test (the RST) Form 4 (Hanna, Schell, and Schreiner, 1977) was used. The reliability of the test is .92. The test contains two subtests: the Word Meaning and the Reading Comprehension subtest. The reason why this test was employed was that it is a test at a level appropriate to discriminate between the subjects in the study.

In fact, the average readability grade of the subjects' reading passages in their books, calculated through the Fog Index Formula (Alderson and Urquhart, 1984) turned out be 12.44 which is close to the average readability grade of the RST reading passages which was 11.91 .

\section{Materials}

The whole instructional program lasted for 13 sessions in each of which one standard cloze passage with the every $7^{\text {th }}$-word deletion ratio was given to the students in the experimental group. The total number of blanks in each passage was at least 25 . The passages were first examined in terms of length, lexis, structure and topic to find out if they were appropriate for conversion into instructional materials for classroom presentation. Then, their average readability grade of each was calculated via the Fog Index Formula. When the readability grade was close to the average readability grade of the subjects' reading passages in their books, they were selected for the treatment phase. The following table presents the readability grade of the 13 cloze passages exploited in this study. 
TABLE 1:

THE READABILITY GRADE OF THE 13 CLOZE PASSAGES

\begin{tabular}{|l|l|l|l|l|l|l|l|l|l|l|l|l|l|}
\hline Passage & 1 & P2 & 3 & 4 & 5 & 6 & 7 & 8 & 9 & 10 & 11 & 12 & 13 \\
\hline Readability & 12.30 & 11.64 & 12,05 & 13.06 & 11.36 & 13.78 & 13.12 & 12.28 & 11.48 & 13.26 & 10.49 & 11.19 & 13.68 \\
\hline
\end{tabular}

The same passages, which were presented to the experimental group in cloze format, were, without any blanks, given by to the students in the control group. Such passages were followed by carefully written comprehension questions. The time allotted to the practice with such passages, whether in cloze format or in full form, was the same, 30 minutes per session.

\section{Procedure}

Before the experiment began, the RST was given to the students in both groups to ascertain that they were at the same of level of reading ability.

Then, as already mentioned, thirteen cloze passages were developed to be used for 13 sessions, one passage per session, in the experimental group. The students were first given time to complete the related cloze passage in each session. Then the teacher checked their answers and supplied them with some explanation when he deemed it necessary.

The students in the control group received the same thirteen passages but in full form. Each passage was followed by carefully written comprehension questions. The students read the passages and answered the questions. Their answers to the questions were checked by the teacher; the students were furnished with explanation whenever deemed necessary by the teacher.

After the 13-session long experimentation was over, the RST was again used to compare the reading ability of the students in the two groups.

\section{E. Data Analysis}

The statistical procedure used in the study included: the t-test technique to compare the two groups in the pretest and posttest stage and the matched t-test technique to compare the two groups on their gain scores.

\section{RESULTS}

To make sure that the two groups were at the same of level of the reading ability at the outset of the study Level A of the Nelson Reading Skills Test (the RST) Form 4 was administered to the students in both groups. The results of the pretest stage are presented in Table 2 below.

TABLE 2:

T-TeSt FOR COMPARING THE PERformance of THE Two Groups AT THE Pretest Stage

\begin{tabular}{|c|c|c|c|c|}
\hline Group & $\overline{\mathrm{x}}$ & $\mathrm{S}$ & $\mathrm{s}\left(\overline{\mathrm{x}}_{\mathrm{e}}-\overline{\mathrm{x}}_{\mathrm{c}}\right)$ & $\mathrm{t}$-observed \\
\hline $\mathrm{G}_{\mathrm{e}}$ & 50.68 & 15.91 & 3.44 & 0.85 \\
$\mathrm{G}_{\mathrm{c}}$ & 53.62 & 13.93 & & $\mathrm{t}$-critical $=2.00$ \\
$\mathrm{P} \leq .05 \quad \mathrm{~N}\left(\mathrm{G}_{\mathrm{e}}\right)=36$ & $\mathrm{df}=74$ \\
$\mathrm{~N}\left(\mathrm{G}_{\mathrm{c}}\right)=40$ \\
Note: The maximum score possible to obtain on the test was 100.
\end{tabular}

As Table 2 demonstrates, there was no significant difference in the reading ability between the two groups in the study.

As was already stated, during the experimentation some students from both groups stopped attending classes and some others failed to take the posttest. Thus, before the post test was given, the scores of these absentees were removed from the pool of those who had taken the original pretest and the t-test was run once again to find out if the two groups would still be statistically the same with respect to the reading ability. Table 3 below presents the results of this second data analysis.

TABLE 3:

SECOND T-TeST FOR COMPARING THE PERFORMANCE OF THE Two GROUPS AT THE PRETEST StaGE

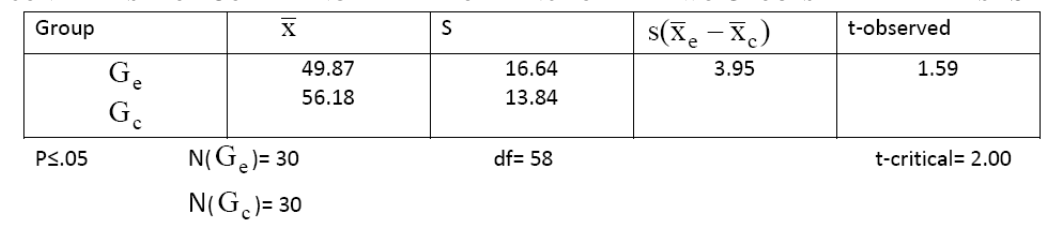

As the facts and figures in Table 3 above indicate, the two groups were still the same after subject mortality was taken care of.

Then, to determine whether there had occurred a significant difference in reading performance between the students in the experimental group and those in the control group after both groups had received instruction, as outlined in 
"Procedure" section, they were compared by means of the RST. The results of the posttest stage are presented in Table 4 below.

TABLE 4:

T-Test For COMPARING THE Performance of the Two Groups at the PostTest Stage

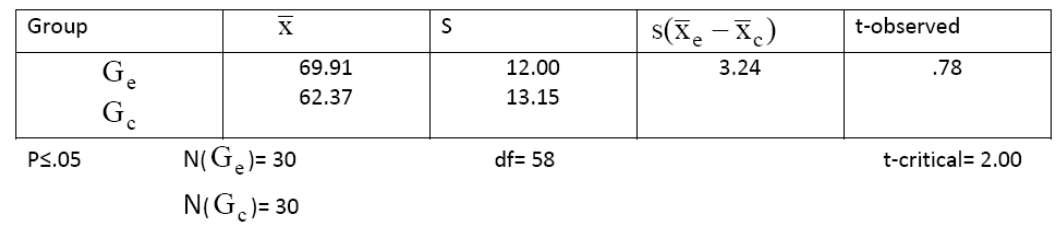

According to Table 4, practice with cloze passages and practice with traditional reading passages resulted in no significant difference in the reading ability of the two groups concerned. However, since the mean score of the experimental group jumped from 49.87 on the pretest to 69.41 on the posttest (15.04 points of improvement) and that of the control group from 56.18 to 62.37 (6.19 points of improvement only), it was decided to compare the improvement of both groups from the pretest to the posttest stage. The results of such a comparison are presented in the following table.

TABLE 5:

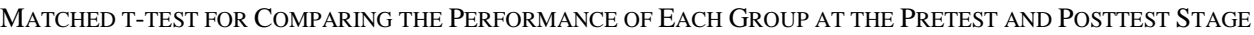

\begin{tabular}{|c|c|c|c|c|c|}
\hline Group & $\mathrm{T}_{1}$ & $T_{2}$ & SD & $S D$ & t-observed \\
\hline $\begin{array}{l}\mathrm{G}_{\mathrm{e}} \\
\mathrm{G}_{\mathrm{c}}\end{array}$ & $\begin{array}{l}49.87 \\
56.18\end{array}$ & $\begin{array}{l}64.91 \\
62.37\end{array}$ & $\begin{array}{l}13.35 \\
11.29\end{array}$ & $\begin{array}{l}2.24 \\
2.06\end{array}$ & $\begin{array}{l}6.16 \\
3.00\end{array}$ \\
\hline
\end{tabular}

As Table 5 illustrates, the reading ability of both groups improved significantly in the course of the project. However, as Table 5 shows the improvement in the experimental group was much higher than the one in the control group. This difference in t-values made the researcher decide to take another step to see whether there was a significant difference in the reading improvement between the two groups. To this end, the gain scores of the groups were calculated and then compared. The results of this comparison are presented in Table 6 below.

TABLE 6:

T-TEST FOR COMPARING THE GAIN SCORES OF THE TwO GROUPS

\begin{tabular}{|c|c|c|c|c|}
\hline Group & $\overline{\mathrm{x}}$ & $\mathrm{S}$ & $\mathrm{s}\left(\overline{\mathrm{x}}_{\mathrm{e}}-\overline{\mathrm{x}}_{\mathrm{c}}\right)$ & $\mathrm{t}$-observed \\
\hline $\mathrm{G}_{\mathrm{e}}$ & 15.04 & 12.45 & 3.04 & 2.91 \\
$\mathrm{G}_{\mathrm{c}}$ & 6.19 & 11.11 & & \\
\hline $\mathrm{P} \leq .05$ & $\mathrm{~N}\left(\mathrm{G}_{\mathrm{e}}\right)=30$ \\
$\mathrm{~N}\left(\mathrm{G}_{\mathrm{c}}\right)=30$ & $\mathrm{df}=58$ & $\mathrm{t}$-critical $=2.00$ \\
\end{tabular}

As shown by Table 6, the difference in the reading improvement between the two groups was significant. More specifically, the experimental group improved more significantly than the control group between the pretest and posttest stage. Therefore, it can be concluded that giving students practice with cloze passages seems to be more effective than the traditional approach to teaching reading comprehension in which students receive practice via passages followed by comprehension check questions.

\section{CONCLUSIONS AND SUGGESTIONS}

The results obtained in this study suggest that regular practice with cloze passages is a very effective technique to develop the reading skill in EFL students and that this type of practice is more fruitful than the type of practice given through reading passages in full followed by comprehension questions of different levels of generality.

The results also seem to buttress the claim made by the schema and psycholinguistic models of reading according to which reading is an active process in which meaning is created by the reader through his background and textual as well as linguistic knowledge. The results thus encourage an approach to reading comprehension teaching in which there should be a component to figure out how readers interpret texts and arrive at answers. Such a component seems much needed to complement the skills-based and language-centered approach which places more premium on the end result of the act of reading than what happens in the process of reading. As Carrel and Eisterhold (1983) state:

... by carefully listening to what our students say about the texts they are asked to read, we can become further sensitized to their hidden comprehension problems. As teachers, we should not respond to what the reader does (right/wrong) as much as to what the reader is trying to do. Given that the reader is trying to make sense of the text (construct meaning, a teacher who listens carefully and responds to a student's efforts will become aware of both the 
background knowledge and the cultural problems that students themselves bring to the text. In any case, the most valuable information is in our students' perceptions and not our own. (PP. 553-573)

Although the cloze procedure can be used to shed light on the mental processes involved in reading, a note of caution should be sounded against any simplistic interpretation of the findings of this study as suggesting that the cloze procedure alone should occupy a disproportionate amount of the books of reading. In fact, all techniques that can simulate the same function that cloze passages fulfill should also be heeded.

For example, in a reading course the think-aloud technique, questions alongside of texts (questions written on the margin of the printed page), and the cloze procedure itself can be used in a harmonious blend to help readers develop strategies such as those referred to by Oxford (1990) (e.g. compensation, cognitive and metacognitive ones). This way the mental processes that readers go through to solve comprehension problems can be identified and if they fall short of applying effective reading strategies, such strategies can be taught to them, thereby complementing their repertoire of reading strategies, part of which has probably been acquired in skills-based or even language-based approaches to the teaching of reading comprehension. How to create such a comprehensive blend of pedagogy is a responsibility upon the shoulders of teachers as well as syllabus designers and material developers.

As a final note, it should also be remembered that in testing programs where applicants' reading comprehension is tested, the inclusion of the cloze procedure may help measure abilities that are sometimes only indirectly tested in multiple-choice forms of tests. In short, due attention to the notion of cloze could help both teaching and testing experts alike to enrich their corpus.

\section{APPENDIX}

$$
\text { تأثير تمرين با آزمون تكميل متن(Cloze) بر مهارت خواندن }
$$

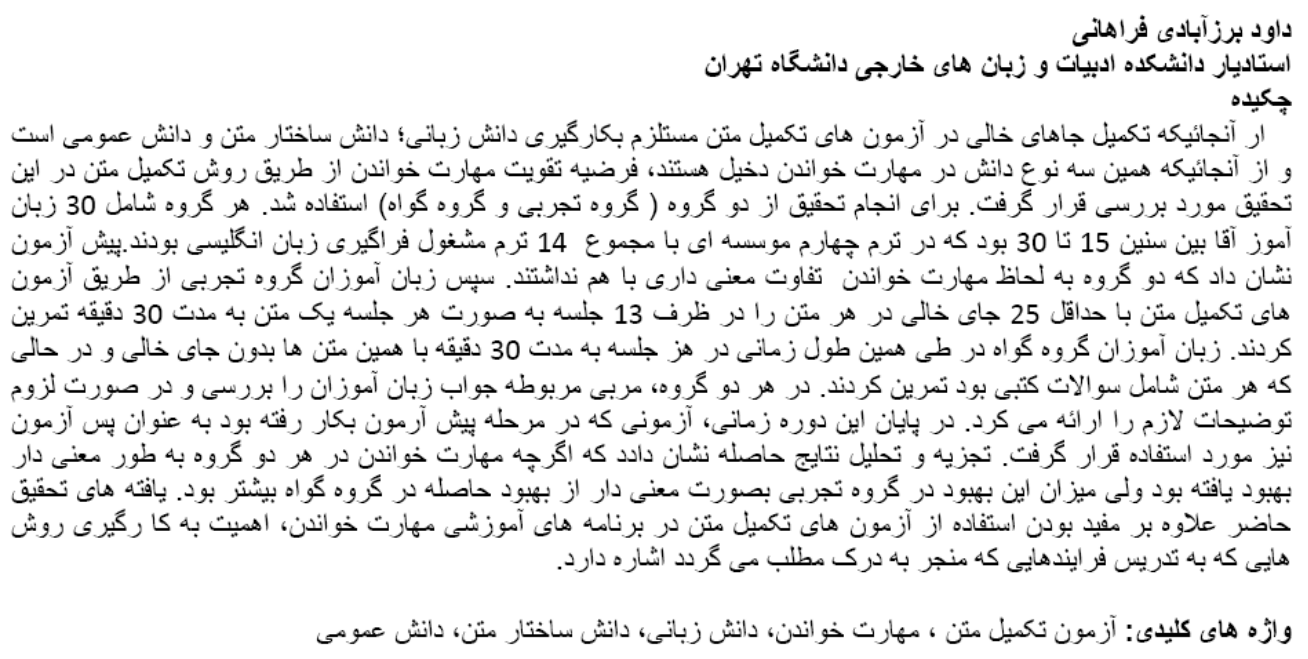

\section{REFERENCES}

[1] Anderson, J. (1976). Psycholinguistic experiments in foreign language testing. Santa Lucia, Queensland, Australia: University of Queensland Press.

[2] Alderson, J.C, and Urquhart. A.H. (1984). Reading in a foreign language. Longman Group: UK

[3] Alderson, J.C. (2000). Assessing reading. Cambridge University Press. Cambridge: UK

[4] Aron, H. (1986). The influence of background knowledge on memory for reading passages by native and nonnative readers. TESOL Quarterly, 20, 136-140.

[5] Bernhardt, E.B. (1991). Reading development in a second language: Theoretical, empirical, and classroom perspectives. Ablex Publishing Corporation, NJ.

[6] Best, B. Z. (1971). The use of cloze techniques in remedial reading. Paper presented at the American Association Conference, New York.

[7] Carrell, P.L. and Eisterhold, J. (1987). Schema theory and ESL reading pedagogy. TESOL Quarterly, 17, 553-573.

[8] Clarke, M.A. and Silberstein, S. (1977). Toward a realization of psycholinguistic principles in the ESL reading class. Language Learning, 27, 1, 48-65.

[9] Cohen, A.D. (1980). Testing language ability in the classroom. Newbury House Publishers.

[10] Eskey, D. E. (2005). Reading in a second language. In E. Hinkel (Ed.), Handbook of research in second language teaching and learning (pp. 563-579), NJ: Lawrence Erlbaum Associates.

[11] Collins-Cheek, M.C. and Cheek, E.H. (1984). Diagnostic-prescriptive reading instruction: A guide for classroom teachers. W.C. Brown Publishers.

[12] Collins-Cheek, M.C., Cheek, E.H. (1984). Diagnostic-prescriptive reading instruction: A guide for classroom teachers. W.C. Brown Publishers. 
[13] Goodman, K.S. (1967). Reading as a psycholinguistic guessing game. Journal of the Reading Specialist, 4, 126-15.

[14] Halliday, M.A.K. and Hasan, R. (1976). Cohesion in English. London. Longmans.

[15] Heaton, J.B. (1975). Writing English language tests. London: Longman.

[16] Hinofotis, F.B. (1980). Cloze testing: an overview. CATESOL Occ. Papers, 6, 51-55.

[17] Hughes, A. (2003) Testing for language teachers. Cambridge University Press. Cambridge: UK

[18] Johnson, P. (1981). Effect of reading comprehension of language complexity and cultural background of a test. TESOL Quarterly, 15. 169-181.

[19] Johnson, P. (1982). Effects of reading comprehension of building background knowledge. TESOL Quarterly, 16, 503-516.

[20] Obah, T. (1983). Prior knowledge and the quest for new knowledge. The third world dilemma. Journal of Reading, 27,129 133.

[21] Kamil, M.L., Intrator, S.M., and Kim, H.S. (2000). The effects of other technologies on literacy and literacy learning: In M.L. Kamil, P. B. Mosenthal, Pearson P.D., and R. Barr (Eds.),Handbook of Reading Research, Vol. III (pp.771-788), Mahwah, NJ: Lawrence Erlbaum Associates.

[22] Koda. K. (2005). Insights into second language reading. Cambridge University Press.

[23] Lee, S.H. (2008). Beyond reading and proficiency assessment: The rational cloze procedure as stimulus for integrated reading, writing, and vocabulary instruction and teacher-student interaction in ESL. System, 36, 442-460.

[24] Lunzer., E. and Gardner, K.( 1979). The effective use of reading. London: Heinemann.

[25] Nelson, G.L. (1987). Culture's role in reading comprehension: A schema theoretical approach. Journal of Reading, 27, $129-133$.

[26] Oxford, R.L. (1990). Language learning strategies: What every teacher should know. New York: Newbury House.

[27] Potter, T.C. (1968). A taxonomy of cloze research, part I: Readability and reading comprehension. Inglewood, California: Southwestern Regional Laboratory for Educational Research and Development.

[28] Ruddell, R.B. (1965). Reading comprehension and structural redundancy in written material. Proceedings of the International Reading Association, 10, 308-311.

[29] Rye, J. (1980). Group cloze and learning. Language for Learning 2, 43-49.

[30] Stafford, C. (1976). A psycholinguistic analysis of ESL reading difficulties with teaching application. Unpublished MA thesis in TESL, University of California, Los Angeles.

[31] Stanovich, K. E. (1992). Speculations on the causes and consequences of individual differences in early reading acquisition. In P. Gough, L. Ehri, \& R. Treirman (Eds.), Reading acquisition (pp. 307-342). Hillsdale NJ: Lawrence Erlbaum Associates.

[32] Steffensen, M.S., Joag-dev, C. and Anderson, R.C. (1979). A cross-cultural perspective on reading comprehension. Reading Research Quarterly, 15, 10-29.

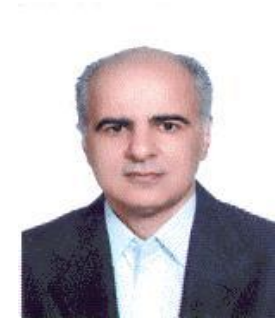

Davood Borzabadi Farahani was born in Tehran, Iran in 1962. He received his university degrees from two state universities in the capital city of Tehran in Iran. More specifically, he received his B.A. degree in English translation from Allame Tabatabee University, his M.A. in TEFL from the University of Tehran and his Ph.D. from Allame Tabatabee University in the years 1989, 1991, and 2000, respectively.

He has been teaching English at the University of Tehran and other language institutes for the past twenty years. In fact, he is a faculty member of the English Department of the College of Foreign Languages and Literatures at the University of Tehran. He is also a test developer at a state-run testing organization named the National Organization for Educational Testing (NOET).

Dr. Borzabadi has so far published several research articles in Iranian applied linguistics journals. Among such articles are The Teacher Parameter in the Postmethod Era (2007), Evaluation of the Construct Validity and Reliability of Language Learning Styles Instruments (2008), and Investigation the Construct Validity and Reliability of Oxford's Strategy Inventory for Language Learning (SILL) (2009). 